\title{
An Overview of Inquiry-Based Science Instruction Amid Challenges
}

\author{
Christian Bob Nicol ${ }^{1 *}$ \\ ${ }^{1} \mathrm{PhD}$ student in Chemistry Education at the African Center of Excellence for Innovative Teaching and Learning Mathematics and \\ Science (ACEITLMS), College of Education, University of Rwanda, RWANDA
}

Received 10 January $2021 \cdot$ Accepted 7 March 2021

\begin{abstract}
Despite efforts to incorporate inquiry-based instruction into various science curricular, its adoption has been slow-paced. This has raised many concerns about challenges in the enactment of inquiry-based instruction. Therefore, this article seeks to provide an understanding of the challenges by exploring the perspectives of teachers in the research literature, as well as suggest possible ways of coping with these challenges. The review of literature has indicated that the identification of what constitutes appropriate guidance in inquiry-based instruction, the threat of time management, teachers' deficiency in inquiry instructional techniques and strategies constitute the most challenges. Although there are strong criticisms against guided inquiry instruction, this study has found that it represents the most appropriate guidance for optimal science learning. A sustained all-year-round training program with support from teaching colleagues and from administration may certainly impact teachers' self-efficacy in inquiry instruction. With the level of progress made in inquiry instruction research, and the pace of advancement of technology, the future of the adoption and enactment of inquiry in the classroom can only be brighter. Future research needs to focus on determining the effects of a more sustained all-year-round professional development model on the level of teachers' achievement in inquiry-based instruction.
\end{abstract}

Keywords: appropriate guidance, challenges in inquiry instruction, Inquiry-based instruction, teaching strategies, teachers' perspectives

\section{INTRODUCTION}

Despite the many curriculum reform programs that have highlighted inquiry-based instruction based on its numerous benefits to students' learning (NRC, 2000), accumulated empirical evidence suggests that this method of instruction is uncommon among teachers (Capps \& Crawford, 2013; Colburn, 2000; Dudu, 2015, Tang et al., 2019). As such, Marshall and Smart (2013) opine that the achievement of science inquiry instruction on a larger scale is farfetched. However, given the importance ascribed to it and the level of teachers' professional development efforts aimed at achieving its large-scale adoption, one might wonder why the practice has not gained an acceptable level of adoption (Bybee et al., 2006).

If the quality of inquiry-based instruction and the level of its adoption should improve, the author argues that the challenges that face this mode of instruction need to be addressed in the research literature with practical solutions proffered. In light of these considerations, this review aims to provide an overview of major inquiry-based instructional challenges as experienced by teachers. It also takes into account the perspectives of educational researchers. The author discusses these challenges as they relate to the meaning of inquiry-based instruction, the structure of scientific inquiry and divergent perspectives of what constitutes appropriate guidance, the time element, teachers' deficiencies in inquiry-based instruction and professional development outcomes. The author assumes that clear insight into these elements will provide a deeper theoretical understanding of the background to the challenges, as well as provide the basis for achieving the learning goals in science inquirybased instruction.

(c) 2021 by the authors; licensee Modestum. This article is an open access article distributed under the terms and conditions of the Creative Commons Attribution License (http://creativecommons.org/licenses/by/4.0/). 


\section{Contribution to the literature}

- This review has established that with proper planning, knowledge of the structure and sequence of topics in the curriculum, the availability of curricular resources with improvisation where necessary, and the right pedagogical skills that integrate technology, the delivery of an inquiry-based science lesson can be achievable in a time-efficient manner.

- A sustained all-year-round training program with support from teaching colleagues and from administration may impact teachers' self-efficacy in inquiry instruction.

- With the level of progress made in inquiry instruction research, and the pace of advancement of technology, the future for the adoption and enactment of inquiry in the classroom can only be brighter.

\section{METHODS}

Sources of information for this review were peerreviewed published journal articles, conference proceedings, reports and books. The search was made in various electronic data bases including ERIC, ProQuest, Research 4 life, Google Scholar and EBSCO between June and October, 2020. Key words and phrases in the search process included; inquiry-based science instruction, challenges in inquiry instruction and history of science inquiry instruction.

\section{Perspectives on the Meaning of Inquiry-Based Instruction}

Although the word "inquiry" in common usage may refer to an investigative endeavor that requires a deeper examination of the subject of an investigation to generate knowledge, a large research literature base reveals diverging and sometimes confusing viewpoints on what constitutes scientific inquiry instruction (Marshall et al., 2016). Some scholars merely equate it with hands-on activities. For instance, Colburn (2000, p. 42) describes it as "the creation of a classroom where students are engaged in essentially open-ended student-centered, hands-on activities". Such confusions perpetuated by science education scholars and practitioners would only confound the concept of inquiry-based instruction for beginning teachers.

It is claimed by the generative theory of learning that cognitive activities in learning, which engage learners in questions, answers and discussions contribute more to learning than behavioural ones (Mayer et al., 2009). According to the authors, learners are subjected to rigorous mental processes when they attempt to answer questions as this process involves selecting the relevant information, organizing it mentally and integrating the organized information with prior knowledge. As DeMeo (2014) claims that the mind has always been more superior to the hand when it comes to learning science, it may seem imperative for teachers to allot more class time to question and answer sessions, where learners will also be given the opportunity to practice scientific questioning skills. In support of this view, the National Research Council (NRC, 1996) recommends exploring authentic questions from students' experiences to be key to the success of inquiry science teaching. According to Minstrell (2000), scientific inquiry arises from curiosity, which naturally leads to questioning. The information in the answers to such questions serve as the building blocks for the construction of knowledge. However, the method used to construct the blocks depends on the constructor of the knowledge (Reiff et al., 2002). This implies that the amount and type of knowledge that can be constructed in a science inquiry classroom would depend on the questioning skills of science teachers.

Making the clarification on which activities do, and which do not constitute inquiry instruction, Bell et al. (2005) explain that while many hands-on activities may be worthwhile, if the learners are not involved in the analysis of data that they generate to answer a research question, the activity may not qualify as an inquiry but may rather be simply referred to as a hands-on activity. This implies that asking students to plot a data set taken from a textbook is not an inquiry activity because the students did not generate the data on their own.

Specifying the steps in the process, Bybee (2004), and DeBoer (2004) highlight that scientific inquiry entails the processes of investigating a perplexing phenomenon, developing a design for investigation in a bid to solve a problem, upholding the values and essence of scientific investigation and ensuring the development of learners' knowledge about science. Therefore, teachers' misconceptions on what inquiry-based instructions entail should be corrected at all cost if they should shift from traditional science teaching practices.

Irrespective of the lack of consensual definition and perspectives, it seems clear that inquiry-based instruction mirrors the processes and procedures that are patterned after practising scientists to a large extent; requiring a research question, which learners seek to address through behavioral and cognitive activities that generate data. Questions and the discussions that they generate in inquiry classes essentially trigger and develop critical thinking in learners. While it may not always lead to the right answers, inquiry-based instruction of science must focus on engaging learners in meaningful hands-on and minds-on activities. 
Table 1. The Roles of Teachers and Learners in Guided Inquiry Laboratory Instruction

\begin{tabular}{lcll}
\hline Authors & Assigned number & Teachers' Role & Students' Role \\
\hline $\begin{array}{l}\text { Banchi and Bell } \\
(2008)\end{array}$ & 3 & Research question & $\begin{array}{l}\text { Procedure, collecting data, analyzing data, } \\
\text { communicating findings and conclusion }\end{array}$ \\
$\begin{array}{l}\text { Bell, Smetana, and } \\
\text { Binns, (2005) }\end{array}$ & 3 & Research question & $\begin{array}{l}\text { Hypothesis, design/procedure, data analysis, } \\
\text { communication of findings and conclusion }\end{array}$ \\
$\begin{array}{l}\text { Buck, Bretz, and } \\
\text { Towns (2008) }\end{array}$ & 1 & $\begin{array}{l}\text { Research question, background, } \\
\text { procedure design of experiment }\end{array}$ & $\begin{array}{l}\text { Data collection, result/data analysis, results } \\
\text { communication and conclusion }\end{array}$ \\
Colburn (2000) & & Materials and procedure & data collection, data analysis, reporting \\
\hline
\end{tabular}

Source: Authors' Review Data (2020)

Total guidance
Verification
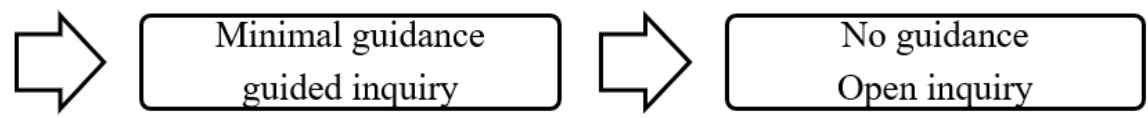

Figure 1. The level of guidance practiced in an inquiry process

\section{Structure or Levels of Inquiry}

In a bid to make inquiry instruction more objectively measurable, various scales have been developed, most of which classify levels of inquiry-based instruction of science on the basis of teachers' support to students and the students' level of involvement in the inquiry process. In one of these, Staver and Bay (1987) present four variants of inquiry, named in order of increasing level of students' freedom and involvement in the lesson as; verification, structured inquiry, guided inquiry and open inquiry. However, as indicated in Table 1, there is neither a consensus on what constitutes and delimits the roles of teachers and learners at any given level of inquiry, nor is there any agreement on the numerical assignment to these levels. This disaccord perpetuates confusion about the use of guided inquiry in science instruction. The confusion is obvious about the use of guided science inquiry instruction given this lack of consensus.

\section{Identifying What Constitutes an Appropriate Guidance}

While it is believed that appropriate teacher guidance may yield optimum benefits for inquiry instruction, the critical point remains that the educational research community is divided on, and is still grappling with identifying what constitutes appropriate or optimum guidance (Blanchard, et al., 2010; Buck et al., 2008). In respect of this, Yerrick (2000), Marshall and Smart (2013) expressed concerns that the expectations of the science education community about inquiry-based instruction research were not being met.

The level of guidance practiced in an inquiry process can be placed into three broad categories for the sake of ease of demonstration as total guidance, minimal guidance and no guidance as shown in Figure 1. Totally guided inquiry instruction (verification), also considered to be the traditional approach, is considered the lowest form of inquiry. It represents a teacher - centered approach to instruction where learners are passive recipients of information in the classroom. In the laboratory, learners follow in a step- by step fashion what the instructor demonstrates (Blanchard et al., 2010). Whereas learners may learn a particular laboratory technique (Buck et al., 2008), a wide section of the educational research community is recommending a shift from this approach of teaching, however, it is considered among scholars that it may be the most suited for novice learners who may need direct guidance throughout on science concepts and experimental procedures.

Minimal guidance, or its pedagogical equivalence, inquiry learning (Papert, 1980) is higher than the total guided inquiry on the inquiry continuum. The perspective of proponents of minimal guidance as well as empirical evidence suggest that this level of guidance grants learners' sufficient autonomy for exploration and independence in critical thinking (Blanchard et al., 2010). However, some of its most referenced critics who define it as an "approach in which learners, rather than being presented with essential information, must discover or construct essential information for themselves" (Klahr \& Nigam, 2004 p. 1) claim that it imposes cognitive overload on learners. According to Sweller (2003), cognitive load is the burden imposed on the working memory as a result of the absence of requisite schemas upon which learners can build new knowledge.

Open (unguided) inquiry requires learners to carry out a scientific investigation unguided. According to Blanchard et al. (2010), open science inquiry instruction requires that the learners have prior knowledge and skills as well as experience with scientific inquiry. It stands to reason that learners will be more cognitively overloaded in an open inquiry learning than in the minimal guided learning environment, and critics of minimal guidance have reason to believe that unguided inquiry impairs learning the most. In fact, Settlage (2007) 
refers to open scientific inquiry as impracticable and unrealistic for high school science education. Therefore, it is reasonable to believe that open scientific inquiry may not be the best suited form for amateur learners.

So, which level of guidance is appropriate for optimal learning? The most logical level of an appropriate guidance must reflect a balance between learners and teacher involvement in the inquiry process and must therefore lie between the extremes of verification and open inquiry in the inquiry continuum. Blanchard et al. (2010) express outright that there is no optimal level of inquiry, adding that in a dynamic class, the designations of levels of inquiry may not be clear cut and that the level of guidance depends on a number of factors including the teachers' goal for the inquiry, the knowledge and skill levels of the learners, the prevailing context and environment, the materials and resources available. Notwithstanding, numerous empirical studies as well as individual researcher perspectives have indicated effective learning by inquiry to be sufficiently guided (Furtak et al., 2012; Minner et al., 2010; Schroeder et al., 2007).

While there may not be any definite prescribed formula for attaining appropriate guidance in inquirybased instruction, it seems clear that since the degree of inquiry and therefore, the level of guidance and support depend on who is responsible for the inquiry activity, the instructor who becomes facilitator may provide vital kick-starter guidance on a minimal scale that is time and resource appropriate to learners (Blanchard et al., 2010). Teacher guidance and support for optimal learning gain also seems to be more importantly dependent on teachers' understanding of the "when", "how" and "what" of guidance. This will ensure a compromise between fully stretching learners' cognitive abilities while ensuring that they are not cognitively overloaded. This may be a plausible way to attaining appropriate guidance in scientific inquiry.

\section{The Time Element}

Time and energy cost for an inquiry-based science lesson preparation for learners' meaningful exploration and discussion in class have been cited among the reasons why teachers do not prefer inquiry-based methods (Costenson \& Lawson, 1986). Unlike an expository lesson teacher, an inquiry-based lesson teacher invests a huge chunk of time amassing a variety of resources in preparing for an interesting lesson that will arouse learners' curiosity (Marx et al., 1997). More importantly, most teachers have stated that the curriculum prescribes large content material that often need to be completed within a relatively short contact time (Alhendal et al, 2015; Gelder et al., 2015; Marx et al., 2004). As a result, teachers have to either choose between superficial expository teaching that offers speed and promise timely completion, or invest more time in deeply engaging learners in exploration and thoughtrelated processes skills that go beyond mastery of the content. Gunstone and Champagne (1990) explain that students will experience meaningful inquiry experience only if they have sufficient time and opportunity for interaction, and reflection on central ideas on the concepts taught.

Teachers may try to strike a balance between content coverage and learners' engagement, but the time and energy demands soon wear them out and they see themselves reverting to expository teaching (Costenson \& Lawson, 1986). However, the author believes that teachers can enhance the pace of instruction and be able to complete teaching of the subject content within the given time if they invest sufficient time in mastering the structure and content of the curriculum, planning the lesson, practice and perfect their skills in summary writing, and time management. A well thought-out lesson that indicates alongside every activity, the time allotted for completion of the activity will save time if the teacher sticks to the plan. Teachers need to think very critically about the most needed information as well as the best approach to teach it that will save time. This means that science teachers would need to move away from giving wordy lesson notes to learners in high schools. This will also require that teachers summarize texts taken from diverse sources, which are predominantly textbooks, condense relevant examinable components using the appropriate contexts to compose a student-friendly lesson material. Learners' in-depth explorations, usually in groups as well as interactive and participatory discussions in inquiry classrooms are worth the time invested in inquiry science lessons to train future scientists.

\section{Deficiency in Inquiry Instructional Techniques and Strategies}

Compared with teachers' level of academic attainment and teaching experience, appropriate teaching strategies have been reported to contribute more to academic achievement in science classes (Hofstein \& Lunetta, 2004; Tobin, 1990). Deficiencies in pedagogical content knowledge demonstrated by teachers perpetuate misconceptions among them (Anderson, 1996; Gutierez, 2015; Johnson, 2007; Nompula, 2012; NRC, 2000; Paulson et al., 2009). Therefore, Chichekian et al. (2016) suggest regular inservice training to scaffold new and less prepared teachers through inquiry-based instructional techniques. For trained and qualified teachers who may teach inquiry techniques, the concern is most often large class size and its implication on classroom management (Alhendal et al., 2015; Gelder et al., 2015; Quigley et al., 2011).

Although a paucity of studies has found that even if the teachers are trained in inquiry instruction and have 
the right class sizes, supplies of materials and resources are just not available, or are in short supply to engage learners in hands-on activities (Baur \& Kenton, 2005; Nompula, 2012). It seems obvious that if a teacher who has the right pedagogical skills could identify curricular resources and endeavor to improvise for the most basic material needs where necessary, as well as integrate technology, this may effectively enhance the delivery of an inquiry-based lesson in a time-efficient manner.

Also, Lemov (2010) encourages teachers to provide learners with the opportunity to ask questions, state hypothesis and suggest the design of experiments. Besides, they emphasize the need to embark on frequent comprehension checks and deep reflections: asking open-ended types of questions, waiting a few seconds to allow the learner to think and cognitively process the information before answering, responding to answers by repeating the answer or paraphrasing it without any applauds, praises or criticisms, granting learners appropriate freedom by encouraging their ideas and behavior and enforcing classroom management techniques (Colburn, 2000).

\section{Practical Teaching Approaches}

As a diagnostic feature of quality science education reform efforts, inquiry-based instruction is meant to be responsive to learners' needs, with teachers providing the appropriate guidance. In light of this, research outcomes and experience have informed the science education community that learners incline to practical work, preferring it to other forms of active learning (Tesfamariam et al., 2015). Practical teaching techniques and strategies have long been accepted and reported to enthuse learners and are therefore critical to enhancing student learning outcomes. Besides, a great many science scholars have recognized worthwhile practical experiences whether in the laboratory, field or classroom, to contribute to meaning-making in the learning process. NRC (1996) also emphasizes the central role of scientific inquiry in the forms of practical work for the achievement of scientific literacy. A purposeful practical work has the potential to develop important high-order learning skills at high school such as asking questions, developing critical thinking, and developing metacognitive skills. Key competencies such as conceptual understanding, understanding of the nature of science, scientific problem-solving skills as well as promoting affective variables like motivation and interests in science, can be enhanced through laboratory activities (Hofstein \& Lunetta, 2004).

\section{Science learning through experiments}

Experiments make-up an important components of science learning, but according to Tesfamariam (2015), it is most often omitted in science instruction for most developing countries due primarily to time and budget constraints as well as inadequate teacher preparation. Lunetta et al. (2007) explains that students waste the very limited time in the laboratory on just reading for comprehension the experimental procedures. This, they claim militates against the acquisition of learners' conceptual and procedural knowledge. As a ripple effect, evidence continues to overwhelm the empirical literature about undergraduate university students' inability to demonstrate sufficient knowledge and skills required at universities (Arum \& Roska, 2011). The need to ensure that practical work in high schools genuinely meets and supports the learning goals is critical to not only their success in higher education, but it also contributes to their life-long learning experiences in the sciences.

As technology continues to have a large influence on education in the Twenty-first century (Abubakar \& Salmanu, 2018), one important thing that it has offered is the creation of a classroom environment that goes beyond the traditional walls of the school (Shapley et al., 2011). Virtual laboratories, as one of the applications of technology in education, have come under the spotlight in the last decade. Debates are raging on whether it can serve as a suitable alternative to physical laboratory given that it allows learners regulate the pace of progress of their lesson; they can pause the lesson and proceed at their convenience, and correct errors by repetition. Besides, it offers learners maximum freedom and autonomy in learning. In fact, Honey and Hilton (2011) add that it alleys the fear of coming into contact with harmful chemical materials, wastage and spillage of chemical materials. Although virtual laboratories have been known to greatly enhance conceptual understanding, critics of virtual laboratory maintain that simulations do not adequately meet an important goal of acquiring science laboratory or manipulative skills (Bilek \& Skalická, 2010). This suggests that physical laboratories are still valued and will continue to be useful in science education. Given the relevance of the two, a combination of virtual and physical laboratory methods is envisaged for attainment of an optimum result in science education.

Koehler and Mishra (2008) explain that the integration of technology into the pedagogy and course content has so far indicated to be the basis for the future of successful science education. Emphasizing the point of integration of these three elements, Conlon and Simpson (2003) caution that while technology in itself makes a big difference in the life of learners, its effect may be counterproductive to educational attainment without pedagogical and content integration. Therefore, these three; pedagogy, content and technology may be considered to constitute mandatory and inseparable components of a twenty first century science instructional approach.

As learning institutions strive to reach out to a more diverse and wider student population across the globe, 
the number of online learning platforms have continued to increase steadily (Allen \& Seaman, 2008; Becker \& Posner, 2012). Recent studies indicate a sharp rise in the demand for online teaching and learning programs especially due to the COVID-19 global pandemic that saw learning activities shut down. As such, most educational institutions have resorted to, and taken advantage of the online teaching and learning platforms (Sahin \& Shelley, 2020). It seems obvious that with the reemergence of the threat of a new and fiercer COVID19 strain, along with pockets of Ebola in parts of central and western African countries, educational institutions should get prepared for a full blown technology-based instruction formats.

\section{Mobile learning}

Mobile learning, defined as a coordinated technology-driven means of acquiring knowledge on a mobile device like smartphone or laptop computers through wireless communication, offers the flexibility of not necessarily having to sit in classrooms or a fixed, predetermined location to learn (O'Malley et al., 2005). Menkhoff and Bengtsson (2012) found that students use mobile learning approaches in a variety of ways to take responsibility for their learning, including communication and information sharing with peers and teachers. In one such application, Menkhoff and Bengtsson (2012) established a collaborative learning website that had featured scholars and authoritative sources of information on the subject matter; crafted a group project so that students could collaborate with peers, communicate their views, share information on their mobile devices and direct queries to their teachers.

Mobile phones and laptops with fast internet connectivity may also be used in class alongside teachers' presentation to aid learners in verifying information in a time-efficient manner: this may be more helpful to learners in large classes to make more and quicker connections between chunks of information and hence make learning more permanent. Although most teachers frown at the idea with the notion that students may be distracted by this approach, McCarthy (2010) argues that it can serve a good purpose if properly coordinated by the teacher. Given that information from authoritative sources can be reached with a click on mobile devices, it should be viewed as an opportunity for enhancing learning in the future. However, experimental studies may need to be carried out especially about attention management in such a class.

\section{Computer-assisted technology}

Amongst the many strategies associated with the use of computer technology is the flipped classroom, a form of blended pedagogy that allows for the combination of an on-site and online experience gathering on a learning goal. Gomez and Rodrieguez-Marcie (2012) compared the learning environments of a flipped classroom and a traditional classroom for a statistics course and found that students in the flipped classroom demonstrated more excitement and openness to cooperation. In agreement with the learning environment theorists' claim, the excitable learning environment leads to a more positive perception about learning (Ginns \& Ellis, 2007).

The use of web-based videos is another digital technology that brings to the doorsteps of learners, resources and information on essentially every topic. A properly designed lesson that integrates this technology with a clear goal in mind is likely to realize its benefits (Krauskopf et al., 2011; Zahn et al., 2010). According to Webb and Cox (2004), the success of the use of this technology relies heavily on planning. Besides, nowadays, with the appropriate procedural knowledge, internet-based software is used not only to improve understanding of science concepts but to raise students' motivation (Mistlerjackson \& Songer, 2000). Probe wares are used to aid learners' graphing and interpretation of data obtained in classroom exploration activities (Dani \& Konieg, 2008). With the use of a digital microscope and laptop computers, learners in a collaborative learning environment can view and analyze video images of microorganisms and the findings shared in a PowerPoint format on a projector to a larger group of students. Digitally-enhanced physical laboratory set-ups seem to be part of the ways we can achieve the goals of the science education in the Twenty-first century.

A breakthrough in classroom instruction that is gradually gathering pace in science education is the electronic voting system (Kennedy \& Cutts, 2005) or the clicker technique (Anderson et al., 2012). This involves students' use of a personal response device called clickers. In its basic operation, students use the clickers, a handheld device similar to a television remote control, to individually select the right answer alternative in multiple-choice items presented on a PowerPoint slide. In a few seconds after voting, the frequency distribution is displayed on a computer screen indicating the numbers of votes per answer alternative. Thereafter, the teacher would call on the students to explain the reason behind their selected answers. The personal response system represents an interesting researchable area as much of the goal of research on it has been to examine learners' views on the use of it: little empirical evidence exists about its effectiveness in enhancing learning.

The impact of this personal response system is further enhanced by embedding peer discussion into the planned lesson activities. In this case, the instructor pauses at an appropriate time in the lesson, projects a few multiple-choice questions on the PowerPoint slide for students to respond to, and after the initial display of the distribution of responses in a histogram, a peer discussion session follows, where students are made to discuss the questions and answers with their peers or in small groups depending on the size of the class. 
Afterwards, students are made to vote their answers again on the same questions to determine any effect of the peer discussion. Smith et al. (2009) indicate that the frequency of the right answer alternative more often than not increases in the second round of voting. The electronic voting system ensures maximum class participation and is best suited for large classes. It should be the most practical solution for developing countries that have fewer schools and large class sizes. However, the wide scale adoption of this technology may be limited by it cost, which may not be affordable by poorer countries.

It is evident that essentially all the new approaches to inquiry-based instruction are related to hard and soft technology. With the eventual rolling out of the Fifth Generation (5G) technology that offers internet connectivity at incredible speed as well as other enhancements that are still yet unknown, coupled with the emergence of artificial intelligence and the momentum of research around the use of technology in education, it stands to reason that new methods of inquiry instruction will continue to evolve with greater advancement in technology. However, wider acceptance and willingness for application will be needed for the full potential to be unlocked.

\section{Challenges with Professional Development}

While professional development endeavours have often been seen as a way to developing teachers' pedagogical skills in a bid to improve the implementation of inquiry instructional practice and its subsequent adoption, this too has largely been counterproductive (Capps et al., 2012). Teachers have more often than not expressed dissatisfaction over the nature of the pieces of training, which they described as heavily lecture-styled and a waste of time (Darling Hammond et al., 2009; Penuel et al., 2007). In these pieces of training, teachers are not given concrete pieces of information and materials to empower them for the task ahead. In addition, they are not totally science specific but rather related to general inquiry teaching strategies.

However, even after acquiring the professional development in inquiry instruction and the training is perceived in a good light by participants, Hoyle and Wallace (2007) explain that the shift from traditional direct teaching methods puts a considerable burden on teachers. As such, they don't get to practice inquirybased instruction upon their return to the classrooms. Yet, the most important means of promoting inquirybased education seems to be a highly organized and purposive professional development. The author believes that it is easier for teachers to teach in ways that they are exposed to. Therefore, professional developments should exactly mirror teachers' engagements in the classrooms. If the teachers can go through training in designing teaching and learning aids, especially in resource-challenged settings, this will be an additional asset for making the work in the classroom both interesting and adventurous.

The processes of instituting inquiry instruction must be a joint endeavor. School administrators, teachers and students should all be involved. In the view of Twigg (2010), having professional collaboration among colleague teachers in the same departments when implementing inquiry instruction in schools can help provide collegial support. In the author's view, if teachers take turns to observe their colleagues teach and afterwards provide them constructive feedbacks on their strengths and weaknesses in debriefing sessions, it may improve their self-efficacies, and with daily improvement, interest in the practice will grow and become more permanent. Above all, teachers' optimism that inquiry instruction work is critical to the success of its implementation. The author believes that the success of inquiry-based instruction lies hugely with human perception and motivation.

In any case, research has shown that short term training of teachers on inquiry instruction tends not to result in changes to teachers' practice (Yoon et al., 2007). Therefore, for sustainability, it is the author's view that professional development programs should be an allyear-round program, with monthly regular workshops, weekly meetings and daily co-teaching followed by debriefings. It will take establishing and promoting collaborations among teachers with the support of the administration. Teachers would require sustained support to maximally inculcate the practice and enjoy doing it.

\section{Criticism about the Effectiveness of Inquiry-based Instruction}

While Hofstein and Mamlok-Naaman (2007) claim that the research literature is unclear on the effectiveness of the inquiry-based instruction in enhancing conceptual understanding generally, strong opponents and critics of guided inquiry argue that there is no evidence in support of the claim that learning is better enhanced when partial rather than full information on concepts and procedures are provided to learners. They suggest that novice learners, in particular, should be provided with direct instructional guidance required by the discipline (Kirschner et al., 2006; Klahr \& Nigam, 2004; Paas et al., 2003). Besides, Tan et al. (2014) explain that most of the studies that demonstrate improvement in learning by inquiry-based instructions are based on rather small, country-specific samples, which inherently limits the generalizability of the findings. Also, Kirschner et al. (2006) support this claim in their explanation that most learners irrespective of age know how to construct knowledge when given adequate information. In the same vein, Yerrick (2000) added that guided inquiry cannot meet the needs for authority and content coverage. These criticisms have continued to accompany 
guided inquiry instruction and thus needs to be addressed in a more rigorous study.

\section{CONCLUSION}

This article aimed to review the most outstanding challenges that confront inquiry-based science instruction. Principal amongst these are the different meanings and interpretations of the term inquiryinstruction and hence the structure of its levels, the confusion about what constitutes appropriate inquiry, the threat of time management, teachers' deficiencies in instructional methods and the inappropriate professional development programs. Although there are strong criticisms against guided inquiry, this review has demonstrated that it may represent the most appropriate guidance for optimal science learning for the following reasons. First, its central placement on the inquiry continuum inherently minimizes the weaknesses of both extremes and consolidates their strengths. Second, stronger evidence and argument in the literature suggest that the most effective inquiry science learning is one that is guided. Third, the fact that the task of knowledge construction is shared between learner and teacher to essentially equal extent reduces cognitive overload, which in turn maximizes learning outcomes.

It is the view of the author that with proper planning, knowledge of the structure and sequence of topics in the curriculum, the availability of curricular resources with improvisation where necessary, and the right pedagogical skills that integrate technology, the delivery of an inquiry-based science lesson can be achievable in a time-efficient manner. All of the aforementioned can be enhanced through a sustained all-year-round training program with support from teaching colleagues and from school administration. With the level of progress made in inquiry instruction research, and the pace of advancement in technology, the way forward for inquiry-based science instruction includes a more purposeful professional development drive in science education institutions aimed at reducing teachers' anxieties and enhancing their confidence and selfefficacies. In this regard, future research should focus on determining the comparative effects of the challenges that stand in the way of inquiry-based instruction since this will inform important decisions for research and practice.

Funding: This study is funded by African Center of Excellence for Innovative Teaching and Learning Mathematics and Science (ACEITLMS), College of Education, University of Rwanda.

Declaration of interest: No conflict of interest is declared by author.

\section{REFERENCES}

Abubakarr, H., \& Salmanu, Y. (2018). Impact of internet technology usage on job performance of senior secondary school teachers in Kaduna State, Nigeria.
International Journal of Curriculum and Instruction 10(2) 152-167.

Alhendal, D., Marshman, M., \& Grootenboer, P. (2015). Kuwaiti science teachers' beliefs and intentions regarding the use of inquiry-based instruction. International Journal of Science and Mathematics Education, 14, 1455-1473. https://doi.org/10.1007/ s10763-015-9671-0

Allen, I. E., \& Seaman, J. (2008). Staying the course: Online education in the United States. The Sloan Consortium. https://onlinelearningsurvey.com/ reports/staying-the-course.pdf

Anderson, L. S., Healy, A. F., Kole, J. A., \& Bourne, L. E. (2012). The clicker technique: cultivating efficient teaching and successful learning. Applied Cognitive Psychology, Appl. Cognitive Psychology, 27(2), 222234. https:/ / doi.org/10.1002/ acp.2899

Anderson, R. D. (1996). Study of curriculum reform. US Government Printing Office.

Anderson, R. D. (2002). Reforming science teaching: What research says about inquiry. Journal of Science Teacher Education, 13(1), 1-12. https://doi.org/ 10.1023/A:1015171124982

Arum, R., \& Roksa, J. (2011). Limited learning on college campuses. Society, 48, Article 203. https:/ / doi.org/10.1007/s12115-011-9417-8

Banchi, H. \& Bell, R. (2008). The many levels of inquiry. Science and Children, 46(2), 26-29.

Bauer, J., \& Kenton, J. (2005). Toward technology integration in the schools: why it isn't happening. The Journal of Technology and Teacher Education, 13, 519-546.

Bell, R. L., Smetana, L., \& Binns, I. (2005). Simplifying inquiry instruction. The Science Teacher, 72(7), 30-33.

Bílek, M., \& Kmet'ová, J. (2010). Current challenges for computer supported school chemical experiments. Problems of education in the 21st Century, 24, 58-65. https://www.researchgate.net/publication/22853 4562

Blanchard, M. R., Southerland, S. A., Osborne, J. W., Sampson, V. D., Annetta, L. A., \& Granger, E. M. (2010). Is inquiry possible in light of accountability? A quantitative comparison of the relative effectiveness of guided inquiry and verification laboratory instruction. Science Education, 94(4), 577616. https:// doi.org/10.1002/sce.20390

Buck, L. B., Bretz, S. L., \& Towns, M. H. (2008). Characterizing the level of inquiry in the undergraduate laboratory. Journal of College Science Teaching, 37(7), 52-58.

Bybee, R. W. (1987). Science education and the sciencetechnology-society (S-T-S) theme. Science Education, 71(5), 667-683. https://doi.org/10.1002/sce. 3730710504 
Bybee, R. W. (2004). Science inquiry and science teaching. In L. B. Flick, \& N. G. Lederman, Scientific Inquiry and Nature of Science. Implications for Teaching, Learning, and Teacher Education (pp. 1-12). Kluwer Academic Publishers.

Bybee, R. W., Taylor, J. A., Gardner, A., Scotter, P. V., Powell, J. C., Westbrook, A., \& Landes, N. (2006). The BSCS 5E instructional model; origins, effectiveness and applications. Colorado Springs.

Capps, D. K., \& Crawford, B. (2013). Inquiry-based professional development: What does it take to support teachers in learning about inquiry and nature of science? International Journal of Science Education, 35(12), 1947-1978. https://doi.org/ 10.1080/09500693.2012.760209

Capps, D. K., Crawford, B. A., \& Constas, M. A. (2012). A review of empirical literature on inquiry professional development: Alignment with best practices and a critique of the findings. Journal of Science Teacher Education, 23(3), 291-318. https: / / doi.org/10.1007/s10972-012-9314-Z

Chichekian, T., Shore, B. M., \& Tabatabai, D. (2016). FirstYear Teachers' Uphill Struggle to Implement Inquiry Instruction: Exploring tnterplay among self-efficacy, conceptualizations, and classroom observations of inquiry enactment. SAGE Open, 6(2), 1-19. https://doi.org/10.1177/215824401664 9011

Colburn, A. (2000). An inquiry primer. Science Scope, 23(6), 42-44.

Conlon, T., \& Simpson, M. (2003). Silicon valley versus silicon glen:the impact of computers upon teaching and learning; acomparative study. British Journal of Educational Technology, 34(2), 137-150. https:/ / doi.org/10.1111/1467-8535.00316

Costenson, K., \& Lawson, A. (1986). Why Isn't Inquiry Used in More Classrooms? The American Biology Teacher, 48(3), 150-158. https://doi.org/10.2307/ 4448241

Dani, D., \& Koenig, K. M. (2008). Technology and reform-based science education. Theory and Practice, 47(3), 204-211. https://doi.org/10.1080/00405840 802153825

Darling-Hammond, L., Wei, R., Andree, A., Richardson, N., \& Orphanos, S. (2009, February). Professional learning in the learning profession: A status report on teacher development in the United States and abroad. National Staff Development Council.

Deboer, G. E. (2004). Historical perspectives on inquiry teaching in schools. In L. B. Flick, \& N. G. Lederman (Eds.), Scientific Inquiry and Nature of Science. Implications for Teaching, Learning, and Teacher Education (pp. 17-35). Kluwer Academic Publishers.

Dudu, W. T. (2015). Facilitating Small-Scale Implementation of Inquiry-Based teaching: encounters and experiences of experimento multipliers in one south african province. International Journal of Science and Mathematics Education, 15(4), 625-642. https://doi.org/ $10.1007 /$ s10763-015-9708-4

Furtak, E. M., Seidel, T., Iverson, H., \& Briggs, D. C. (2012). Experimental and quasi-experimental studies of inquiry-based science teaching: A metaanalysis. Review of Educational Research, 82(3), 300329. https:/ / doi.org/10.3102/0034654312457206

Gelder, J. I., Abraham, M. R., \& Greenbowe, T. J. (2015). Teaching electrolysis with guided inquiry. In M. V. Orna (Ed.), Sputnik to Smartphones: A Half-Century of Chemistry Education (pp. 141-154). American Chemical Society. https://doi.org/10.1021/bk2015-1208.ch009

Ginns, P., \& Ellis, R. (2007). Quality in blended learning: Exploring the relationships between on-line and face-to-face teaching and learning. Internet and Higher Education, 10(1), 53-64. https://doi.org/ 10.1016/j.iheduc. 2006.10 .003

Gómez, E., \& Rodríguez-Marciel, C. (2012). PGDnet: A new problemsolving virtual learning environment. British Journal of Educational Technology, 43(4), 576591. https://doi.org/10.1111/j.1467-8535.2011. 01224.x

Gunstone, R. F., \& Chanpagne, A. B. (1990). Promoting conceptual change in the laboratory. In E. HegartyHazel (Ed.), The student laboratory and the science curriculum (pp. 159-182). Routledge.

Gutierez, S. (2015). Collaborative professional learning through lesson study: Identifying the challenges of inquiry - based teaching. Issues in Educational Research, 25(2), 118-134. http://www.iier.org.au/ iier25/gutierez.html

Hofstein, A., \& Lunetta, V. N. (2004). The laboratory in science education: foundation for the 21st century. Science Education, 88(1), 28-54. https://doi.org/ 10.1002/sce.10106

Hofstein, A., \& Mamlock-Naaman (2007). The laboratory in science education: the state of the art. Chemistry Education Research and Practice, 8(2), 105-107. https:/ / doi.org/10.1039/B7RP90003A

Honey, M. A., \& Hilton, M. (Eds.). (2011). Learning science through computer games and simulations. The National Academies Press.

Hoyle, E. P., \& Wallace, M. (2007). Educational reform: An ironic perspective. Educational Management, Administration, and Leadership, 35(1), 9-25. https://doi.org/10.1177/1741143207071383

Johnson, C. C. (2007). Whole-school collaborative sustained professional development and science teacher changes: signs of progress. Journal of Science Teacher Education, 18, 629-661. https:/ / doi.org/10.1007/s10972-007-9043-x 
Kennedy, G. E., \& Cutts, I. Q. (2005). The association between students' use of an electronic voting system and their learning outcomes. Journal of Computer Assisted Learning, 21(4), 260-268. https:/ / doi.org/10.1111/j.1365-2729.2005.00133.x

Kirschner, P. A., Sweller, J., \& Clark, R. E. (2006). Why minimal guidance during instruction does not work: An analysis of the failure of constructivist, discovery, problem-based, experiential, and inquiry-based teaching. Educational Psychologist, 41(2), 75-86. https://doi.org/10.1207/s15326985 ep4102_1

Klahr, D., \& Nigam, M. (2004). The equivalence of learning paths in early science instruction: Effects of direct instruction and discovery learning. Psychological Science, 15(10), 661-667. https:/ / doi.org/10.1111/j.0956-7976.2004.00737.x

Koehler, M. J., \& Mishra, P. (2010). Introducing TPCK. In AACTE committee on innovation and technology (Ed.), Handbook of Technological Pedagogical Contentent Knowledge (tpck) for Educators (pp. 3-30). Routledge.

Krauskopf, K., Zahn, C., \& Hesse, F. (2012). Leveraging the affordances of youtube: The roles of pedagogical knowledge and mental models of technology. Computers and Education, 58(4), 11941206.

https:/ / doi.org/10.1016/j.compedu.2011.12.010

Lemov, D. (2010). Teach Like a Champion-49 Teaching Techniques that put students on the path to College. Jossey- Bass.

Lunetta, V. N., Hofstein, A., \& Clough, M., (2007). Learning and searching in the School science laboratory: An analysis of research, theory, and practice, In N. Leaderman and S. Abel (eds.), Handbook of research on science education (pp. 393441), Lawrence Erlbaum.

Marshall, J. C., \& Smart, J. B. (2013). Teachers' transformation to inquiry-based instructional practice. Creative Education, 4(2), 132-142. https:/ / doi.org/10.4236/ce.2013.42019

Marshall, J. C., Smart, J. B., \& Alston, D. (2016). Inquirybased instruction: A possible solution to improving student learning of both science concepts and scientific practices. International Journal of Science and Mathematics Education, 15(5), 777-796. https:/ / doi.org/10.1007/s10763-016-9718-x

Marx, R. W., Blumenfeld, P. C., Krajcik, J. S., Fishman, B., Soloway, E., Geier, R., \& Tal, R. T. (2004). Inquirybased science in the middle grades: assessment of learning in urban systemic reform. Journal of Research in Science Teaching, 41(10), 1063-1080. http:/ / doi.org/10.1002/tea.20039

Mayer, R. E., Stull, A., Deleeuw, K., Almeroth, K., Bimber, B., Chun, D., Bulger, M., Campbell, J.,
Knight, A., \& Zhang, H. (2008). Clickers in college classrooms: fostering learning with questioning methods on large lecture classes. Contemporary Educational Psychology, 34(1), 51-57. https://doi.org/10.1016/j.cedpsych.2008.04.002

McCarthy, J. (2010). Blended learning environments: Using social networking sites to enhance the first year experience. Australasian Journal of Educational Technology, 26(6), 729-740. https://doi.org/ 10.14742/ajet.1039

Menkhoff, T., \& Bengtsson, M. L. (2012). Engaging students in higher education through mobile learning: lessons learnt in a Chinese entrepreneurship course. Educational Research Policy and Practice, 11(3), 225-242. https://doi.org/10.1007/s10671-011-9123-8

Minner, D. D., Levy, A. J., \& Century, J. (2010). Inquirybased science instruction-what is it and does it matter? Results from a research synthesis years 1984 to 2002. Journal of Research in Science Teaching, 47(4), 474-496. https:/ / doi.org/10.1002/tea.20347

Minstrell, J. (2000). Implications for teaching and learning inquiry: A summary. In J. Minstrell, \& Z. E. Van (Eds.), Inquiring into inquiry learning and teaching in science (pp. 471-496). American Association for the Advancement of Science.

Mistler-Jackson, M., \& Songer, N. B. (2000). Students' motivation and internet technology: Are students empowered to learn science? Journal of Research in Science Teaching, 37(5), 459-479. https://doi.org/ 10.1002/(SICI)1098-2736(200005)37:5<459:AIDTEA5>3.0.CO;2-C

National Research Council. (1996). National science education standards. National Academy Press.

National Research Council. (2000). Inquiry and the National Science Education Standards: A Guide for teaching and learning. The National Academies Press. https:/ / doi.org/10.17226/9596

Nompula, Y. (2012). An investigation of strategies for integrated learning experiences and instruction in the teaching of creative art subjects. South African Journal of Education, 32(3), 293-306. https:/ / doi.org/10.15700/saje.v32n3a579

O’Malley, C., Vavoula, G., Glew, J., Taylor, J., Sharples, M., Lefrere, P., Lonsdale, P., Naismith, L., \& Waycott, J. (2005, March 25). Guidelines for learning/teaching/tutoring in a mobile environment. https:/ / hal.archives-ouvertes.fr/hal-00696244

Paas, F., Renkl, A., \& Sweller, J. (2003). Cognitive load theory and instructional design: Recent developments. Educational Psychology, 38(1), 1-4. https:/ / doi.org/10.1207/S15326985EP3801_1

Papert, S. (1980). Mindstorms - Children, Computers and Powerful Ideas. Basic Books, Inc. 
Paulson, P., Williams-Tuenge, L., Roth, S., Wippler, R., \& Paulson, D. (2009). Inquiry is elementary: Differing approaches to inquiry within two elementary schools. In R. Yager (Ed.), Inquiry: The key to exemplary science (pp. 139-150). NSTA Press.

Penuel, W. R., Fishman, B., Yamaguchi, R., \& Gallagher, L. P. (2007). What makes professional development effective? Strategies that foster curriculum implementation. American Educational Research Journal, 44(4), 921-958. https://doi.org/10.3102/ 0002831207308221

Quigley, C., Mashall, J. C., Deaton, C. C., \& Cook, M. P. (2011). Challenges to inquiry teaching and suggestions for how to meet them. Science Educator, 20(1), 55-61.

Reiff, R., Harwood, W. S., \& Phillipson, T. (2002). A scientific method based upon research scientists' conceptions of scientific inquiry. In Annual International Conference of the Association of Teachers in Science (pp. 1-25). Association for the Education of Teachers in Science.

Sahin, I., \& Shelley, M. (Eds.). (2020). Educational practices during the COVID-19 viral outbreak: International Perspectives. ISTES Organization.

Schroeder, C. M., Scott, T. P., Tolson, H., Huang, T. Y., \& Lee, Y. H. (2007). A meta-analysis of national research: Effects of teaching strategies on student achievement in science in the United States. Journal of Research in Science Teaching, 44(10), 1436-1460. https:/ / doi.org/10.1002/tea.20212

Settlage, J. (2007). Demythologizing science teacher education: Conquering the false ideal of open inquiry. Journal of Science Teacher Education, 18(4), 461-467. https://doi.org/10.1007/s10972-0079060-9

Shapley, K., Sheehan, D., Maloney, C., \& CaranikasWalker, F. (2011). Effects of technology immersion on middle school students' learning opportunities and achievement. The Journal of Educational Research, 104(5), 299-315. https:/ / doi.org/10.1080/ 00220671003767615

Smith, M. K., Wood, W. B., Adams, W. K., Wieman, C., Knight, J. K., Guild, N., \& Su, T. T. (2009). Why peer discussion improves student performance on inclass concept questions. Science, 323(5910), 122-124. https:/ / doi.org/10.1126/science.1165919
Staver, J., \& Bay, M. (1987). Striving for excellence: The National Education Goals. Michigan University.

Sweller, J. (2003). Evolution of human cognitive architecture. In B. Ross (Ed.), The psychology of learning and motivation (pp. 215-266). Academic. https:/ / doi.org/10.1016/S0079-7421(03)01015-6

Tan, A.-L., C. L. Poon, \& S. S. L. Lim (Eds.) (2014). Inquiry into the Singapore science classroom: Research and practices. Springer. https://doi.org/10.1007/978981-4585-78-1

Tang, N.-E., Tsai, C.-L., Barrow, L., \& Romine, W. (2019). Impacts of enquiry-based science teaching on achievement gap between high-and-low SES students: Findings from PISA 2015. International Journal of Science Education, 41(4), 448-470. https:/ / doi.org/10.1080/09500693.2018.1555726

Twigg, V. V. (2010). Teachers' practices, values and beliefs for successful inquiry-based teaching in the international baccalaureate primary years programme. Journal of Research in International Education, 9(1), 40-65. https://doi.org/10.1177/ 1475240909356947

Webb, M., \& Cox, M. (2004). A review of pedagogy related to information and communications technology. Technology, Pedagogy and Education, 13(3), 235-286. https:/ / doi.org/10.1080/147593904 00200183

Yerrick, R. K. (2000). Lower track students' argumentation and open inquiry instruction. Journal of Research in Science Teaching, 37(8), 807-838. https: / / doi.org/10.1002/1098-2736(200010)37:8 $<807::$ AID-TEA4>3.0.CO;2-7

Yoon, K. S., Duncan, T., Lee, S. W.-Y., Scarloss, B., \& Shapley, K. (2007). Reviewing the evidence on how teacher professional development affects student achievement (Issues \& Answers Report, REL 2007-No. 033). U.S. Department of Education, Institute of Education Sciences, National Center for Education Evaluation and Regional Assistance, Regional Educational Laboratory Southwest. http:/ / ies.ed.gov/ncee/edlabs/regions/southwes t/pdf/REL_2007033.pdf

Zahn, C., Pea, R., Hesse, F., Rosen, J. (2010). Comparing simple and advanced video tools as support for complex collaborative design process. Journal of the Learning Sciences, 19(3), 403-440. https://doi.org/ $10.1080 / 10508401003708399$

\section{http://www.ejmste.com}

